\title{
Trends of minimum and maximum temperature in Poland
}

\author{
Joanna Wibig ${ }^{1, *}$, Bronisław Głowicki $^{2}$ \\ ${ }^{1}$ Department of Meteorology and Climatology, University of Łódź, Lipowa 81, 90-568 Łódź, Poland \\ ${ }^{2}$ Institute of Meteorology and Water Management, Branch Wrocław, Parkowa 30, 51-616 Wrocław, Poland
}

\begin{abstract}
The variability of minimum and maximum temperature and the daily temperature range (DTR) in Poland was analyzed on the basis of the data from 9 stations with different periods of data (the longest was $98 \mathrm{yr}$ ). The long-term changes of seasonal means as well as for all Julian days were determined. The increase in the minimum temperature was accompanied by a slighter increase in the maximum temperature and a decrease in the DTR. It was found that the DTR changes correlate well with cloudiness, and the extreme temperature changes are related to the NAO (North Atlantic Oscillation) intensity, especially during winter and spring. The analysis of intra-annual changes has shown that the strongest increase in the minimum and maximum temperatures occurs in mid- and late winter, but there are also periods with decreasing tendencies, i.e. late autumn, the beginning of winter and the beginning of summer. All temperature indices indicate the cooling in autumn.
\end{abstract}

KEY WORDS: Daily minimum and maximum temperature $\cdot$ Daily temperature range $\cdot$ Long-term trends $\cdot$ Poland

Resale or republication not permitted without written consent of the publisher

\section{INTRODUCTION}

According to the Third Assessment Report of the IPCC (the Shanghai draft, 2001, further referred to as TAR; http://www.ipcc.ch), the observed global warming over the 20 th century reached $0.6 \pm 0.2^{\circ} \mathrm{C}$. This change was accompanied by an increase in minimum and maximum temperatures. Karl et al. (1993) have shown that the minimum temperature has risen 2 times faster than the maximum temperature at least in 30\% of the Northern Hemisphere land areas, and that the daily temperature range (DTR) dropped in more than $50 \%$ of the land areas. According to TAR (2001), the night-time air temperature over land increased by about $0.2^{\circ} \mathrm{C}$ decade $^{-1}$ between 1950 and 1993 and the daytime air temperature increased by only $0.1^{\circ} \mathrm{C}$ decade $^{-1}$. Since the analysis of Karl et al. (1993) did not concern Central Europe, only a few papers seem to fill this gap (Böhm \& Auer 1994, Brázdil et al. 1994, Lapin \& Faško 1994, Miętus \& Owczarek 1994, Niedźwiedź \&

*E-mail: zameteo@krysia.uni.lodz.pl
Ustrnul 1994, Weber 1994). Brázdil et al. (1996), summing up these papers, stated that the tendencies in Central and South-Eastern Europe did not follow that suggested by Karl et al. (1993). Trends of the minimum and maximum temperatures exceeded the significance level in some cases only, and the rise of the maximum temperature was higher than that for the minimum. Sometimes they both dropped. In Poland, the increase in maximum and minimum temperatures was significant only in spring and for the whole year, and the maximum temperature increased faster than the minimum temperature, so the DTR also increased, but not in a statistically significant way. At the seaside, however, Miętus \& Owczarek (1994) found an increasing tendency for the mean annual minimum temperature to be significant at a majority of the analyzed sites.

Such a course of changes probably results from the choice of period of analysis. The 20th century warming occurred during 2 periods, 1910-1945 and 1976-2000 (TAR 2001), and between them the temperature decreased. The analysis of longer records, going back to the beginning of the 20th century, pointed out an evi- 
Table 1. Characteristics of the locations of the analyzed stations and data availability

\begin{tabular}{|lccccc|}
\hline Stn & Latitude & Longitude & Elevation (amsl) & Period & Missing periods \\
\hline Śnieżka & $50^{\circ} 44^{\prime} \mathrm{N}$ & $15^{\circ} 44^{\prime} \mathrm{E}$ & 1603 & $1901-1998$ & $1921-1922$ \\
Zakopane & $49^{\circ} 17^{\prime} \mathrm{N}$ & $19^{\circ} 57^{\prime} \mathrm{E}$ & 844 & $1912-1998$ & $1939-1940,1945-1946$ \\
Łódź & $51^{\circ} 44^{\prime} \mathrm{N}$ & $19^{\circ} 24^{\prime} \mathrm{E}$ & 184 & $1931-1998$ & $1921-1922,1939,1945-1946$ \\
Puławy & $51^{\circ} 25^{\prime} \mathrm{N}$ & $21^{\circ} 58^{\prime} \mathrm{E}$ & 142 & $1918-1998$ & $1951-1998$ \\
Poznań & $52^{\circ} 25^{\prime} \mathrm{N}$ & $16^{\circ} 59^{\prime} \mathrm{E}$ & 86 & $1951-1998$ & $1951-1998$ \\
Siedlce & $52^{\circ} 11^{\prime} \mathrm{N}$ & $22^{\circ} 16^{\prime} \mathrm{E}$ & 146 & $1951-1998$ & $1951-1998$ \\
Chojnice & $53^{\circ} 43^{\prime} \mathrm{N}$ & $17^{\circ} 35^{\prime} \mathrm{E}$ & 170 & 140 & \\
Kalisz & $51^{\circ} 44^{\prime} \mathrm{N}$ & $18^{\circ} 05^{\prime} \mathrm{E}$ & 1 & 1988 \\
Hel & $54^{\circ} 36^{\prime} \mathrm{N}$ & $18^{\circ} 49^{\prime} \mathrm{E}$ & & & \\
\hline
\end{tabular}

dent increasing trend for both daily extremes in Central Europe (Brázdil et al. 1996). The increase in temperature in Prague may be due to the urban effect, but Hurbanovo and Hohenpeissenberg represent rural conditions and also manifest significant warming. Also in this case the maximum temperature rises faster than the minimum temperature.

The aim of this paper is to analyze the variability of minimum and maximum temperatures in Poland and the relation to cloudiness and atmospheric circulation variations.

\section{DATA AND METHODS}

In the present analysis the daily minimum and maximum temperatures for 9 stations in Poland were used. A list of stations, their locations and length of records are shown in Fig. 1 and Table 1. The longest record comes from Śnieżka and has been homogenous since

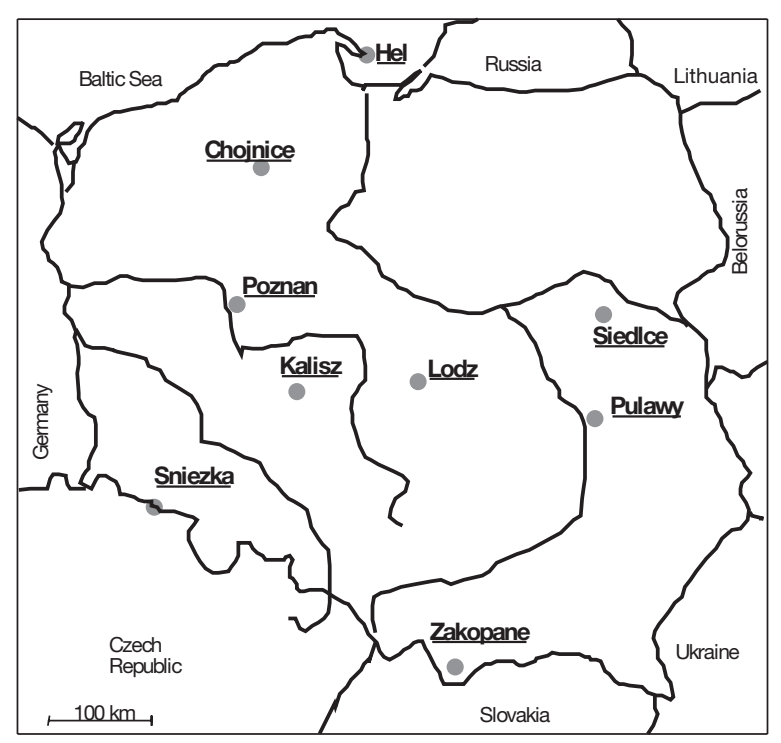

Fig. 1. Locations of the analyzed stations in Poland the beginning of the 20th century (Głowicki 1998). It is a mountain station in the Sudety Mountains in southwestern Poland. The second longest record is from Zakopane, the submontane station in the Tatra Mountains in the south of Poland. All the others are from lowland locations. Hel represents the seashore conditions. Special attention was given to avoiding urbanbiased records. Stations in Łódź and Poznań are located at airports outside of the cities. The record from Zakopane was homogenized because of the change of location in 1967. The homogeneity of records was tested by means of the Alexandersson (1986) test. Each station's values were compared with a reference record calculated from all the other stations with the weighting scheme proposed by Alexandersson (1986). Short gaps in the long-term records from Zakopane, Puławy and Łódź were not filled. The normality of the data distribution was verified by means of SmirnovKolmogorov nonparametric test.

For analysis of the extreme temperature variability a few indices were selected: mean minimum temperature $\left(t_{\mathrm{n}}\right)$, mean maximum temperature $\left(t_{\mathrm{x}}\right)$, DTR, frequency of days with minimum temperature below $0^{\circ} \mathrm{C}$, the so-called cold days $(f C d)$, frequency of days with maximum temperature above $20^{\circ} \mathrm{C}$, the so-called warm days $(f w d)$, the lowest daily minimum temperature $\left(\min t_{\mathrm{n}}\right)$ and the highest daily maximum temperature $\left(\max t_{\mathrm{x}}\right)$. The temporal changes of the annual and seasonal values of these parameters were analyzed by means of a linear trend with Student's $t$-test of significance and the Mann-Kendall rank statistics. The trends at different locations were calculated for the common period 1951-1998 to enable a comparison. Some series, however, allow an evaluation of changes over a longer period.

To explain the observed trends in the minimum and maximum temperatures and the DTR, the linear correlation coefficients with mean annual and seasonal cloudiness were calculated for Śnieżka and Łódź and with the NAO (North Atlantic Oscillation) index defined by Jones et al. (1997) for all stations. The deter- 
Table 2. Equations of linear trends of selected temperature indices in the period 1951-1998. Values are given in bold (italics) if the trend coefficient is significant at $\alpha=0.05(0.10)$. $t_{\mathrm{x}}$ : mean maximum temperature; $f w d$ : frequency of days with maximum temperature above $20^{\circ} \mathrm{C}$, the so-called warm days; $\min t_{\mathrm{n}}$ : lowest daily minimum temperature; maxt $t_{\mathrm{x}}$ : highest daily maximum temperature

\begin{tabular}{|c|c|c|c|c|}
\hline & $t_{\mathrm{x}}$ & $f w d$ & $\min t_{\mathrm{n}}$ & $\max t_{\mathrm{x}}$ \\
\hline Chojnice & $10.752+0.012 \cdot(1950+\mathrm{i})$ & $74.0+0.03 \cdot(1950+i)$ & $-18.816+0.027 \cdot(1950+i)$ & $30.027+0.042 \cdot(1950+i)$ \\
\hline Hel & $10.779+0.011 \cdot(1950+\mathrm{i})$ & $61.2-0.02 \cdot(1950+\mathrm{i})$ & $-13.491+0.059 \cdot(1950+i)$ & $28.979-0.006 \cdot(1950+i)$ \\
\hline Kalisz & $12.192+0.013 \cdot(1950+\mathrm{i})$ & $97.3-0.04 \cdot(1950+\mathrm{i})$ & $-19.827+0.052 \cdot(1950+\mathrm{i})$ & $31.833+0.044 \cdot(1950+i)$ \\
\hline Łódź & $11.870+0.011 \cdot(1950+\mathrm{i})$ & $94.0-0.02 \cdot(1950+\mathrm{i})$ & $-19.827+0.032 \cdot(1950+\mathrm{i})$ & $31.934+0.024 \cdot(1950+i)$ \\
\hline Poznań & $12.336+0.013 \cdot(1950+i)$ & $97.0-0.02 \cdot(1950+\mathrm{i})$ & $-19.703+0.071 \cdot(1950+i)$ & $32.503+0.027 \cdot(1950+i)$ \\
\hline Puławy & $11.976+0.011 \cdot(1950+i)$ & $99.0-0.03 \cdot(1950+\mathrm{i})$ & $-20.669+0.042 \cdot(1950+i)$ & $31.601+0.007 \cdot(1950+i)$ \\
\hline Siedlce & $11.599+0.005 \cdot(1950+i)$ & $97.7-0.13 \cdot(1950+\mathrm{i})$ & $-28.097+0.217 \cdot(1950+i)$ & $31.608+0.000 \cdot(1950+i)$ \\
\hline Śnieżka & $3.054+0.006 \cdot(1950+i)$ & $1.1+0.03 \cdot(1950+i)$ & $-20.888+0.027 \cdot(1950+\mathrm{i})$ & $20.092+0.022 \cdot(1950+i)$ \\
\hline Zakopane & $9.721+0.015 \cdot(1950+i)$ & $51.2+0.08 \cdot(1950+i)$ & $-23.078+0.080 \cdot(1950+i)$ & $27.801+0.004 \cdot(1950+\mathrm{i})$ \\
\hline
\end{tabular}

mination coefficient $D$, defined as the square of a correlation coefficient, was used to describe the degree of common variance of 2 analyzed variables.

\section{VARIABILITY OF MINIMUM AND MAXIMUM TEMPERATURES AND THEIR INDICES (1951-1998)}

\subsection{Annual values (1951-1998)}

The mean maximum temperature exhibits a slight increase everywhere, but according to the MannKendall test, the rise is statistically significant only in Zakopane (Table 2). The mean minimum temperature, however, shows a more evident increase (Fig. 2), significant at all stations. The growth rate varies from $0.14^{\circ} \mathrm{C}$ decade $^{-1}$ in Zakopane to $0.31^{\circ} \mathrm{C}$ decade $^{-1}$ in Kalisz. Such big differences in linear trends of minimum and maximum temperatures have led to a decrease in the DTR (Fig. 3). Only in Zakopane is the DTR rising. At other stations, the decrease in the DTR varies from $0.03^{\circ} \mathrm{C}$ decade $^{-1}$ in Chojnice to $0.18^{\circ} \mathrm{C}$ decade $^{-1}$ in Kalisz, and the decrease is statistically significant at 6 stations. The increase in the minimum temperature is faster than the increase in the maximum temperature, in agreement with the results of Karl et al. (1993) for other regions.

The long-term trend of the highest annual maximum temperature varies considerably in Poland (Table 2). A decreasing tendency was found in Hel, and an increasing tendency occurred at all other stations. Changes in Kalisz and Chojnice, with rates of 0.44 and $0.42^{\circ} \mathrm{C}$ decade $^{-1}$ respectively, are statistically significant. The lowest annual minimum temperature (Table 2) shows an increase at all stations, with the rate varying from $0.27^{\circ} \mathrm{C}$ decade $^{-1}$ in Śnieżka and Chojnice to $2.17^{\circ} \mathrm{C}$ decade $\mathrm{e}^{-1}$ in Siedlce. The $5 \%$ level of statistical significance is exceeded only in Zakopane and a $10 \%$ level of significance is exceeded in Śnieżka.
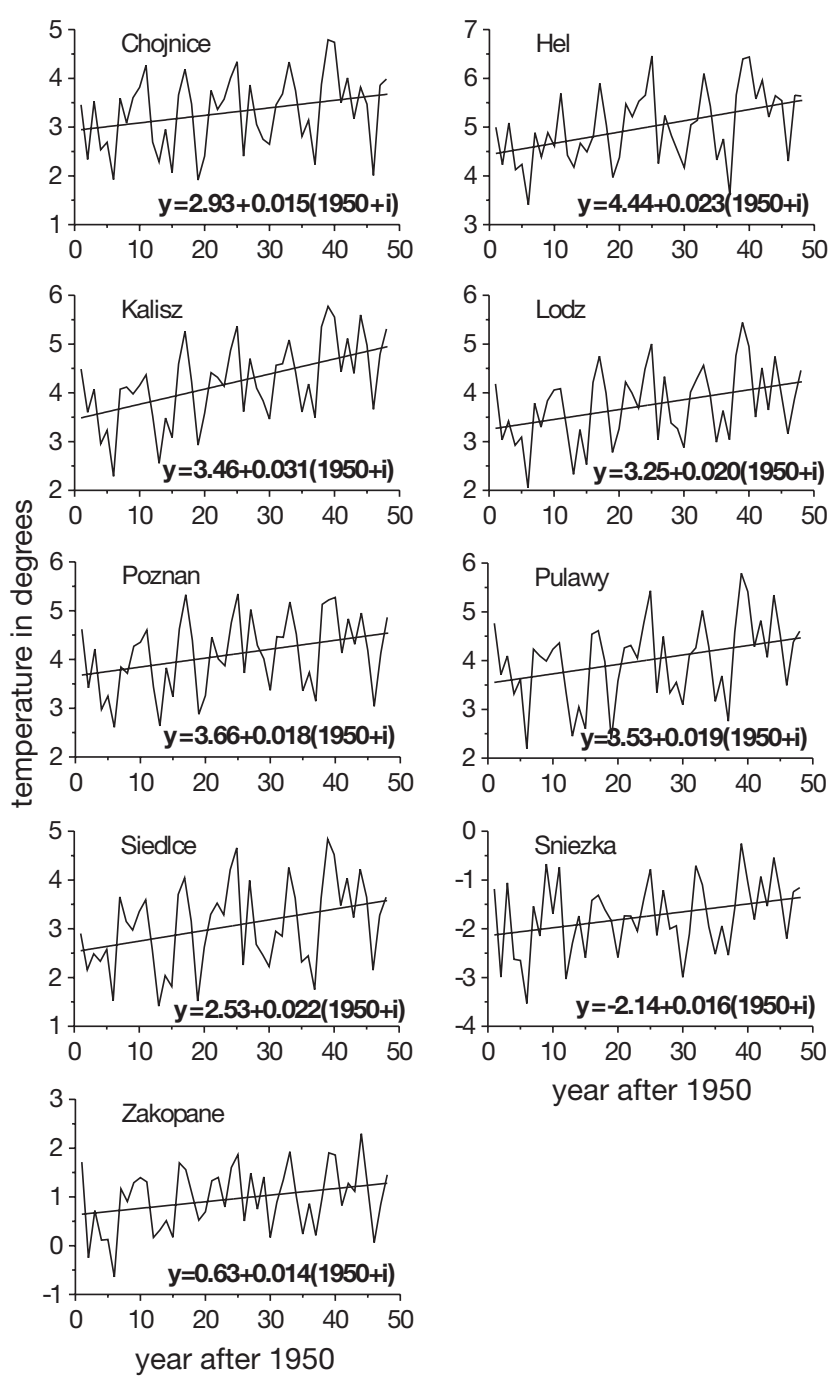

Fig. 2. Mean daily minimum temperature with linear trend. The trend equations statistically significant at $5 \%$ are given in bold 


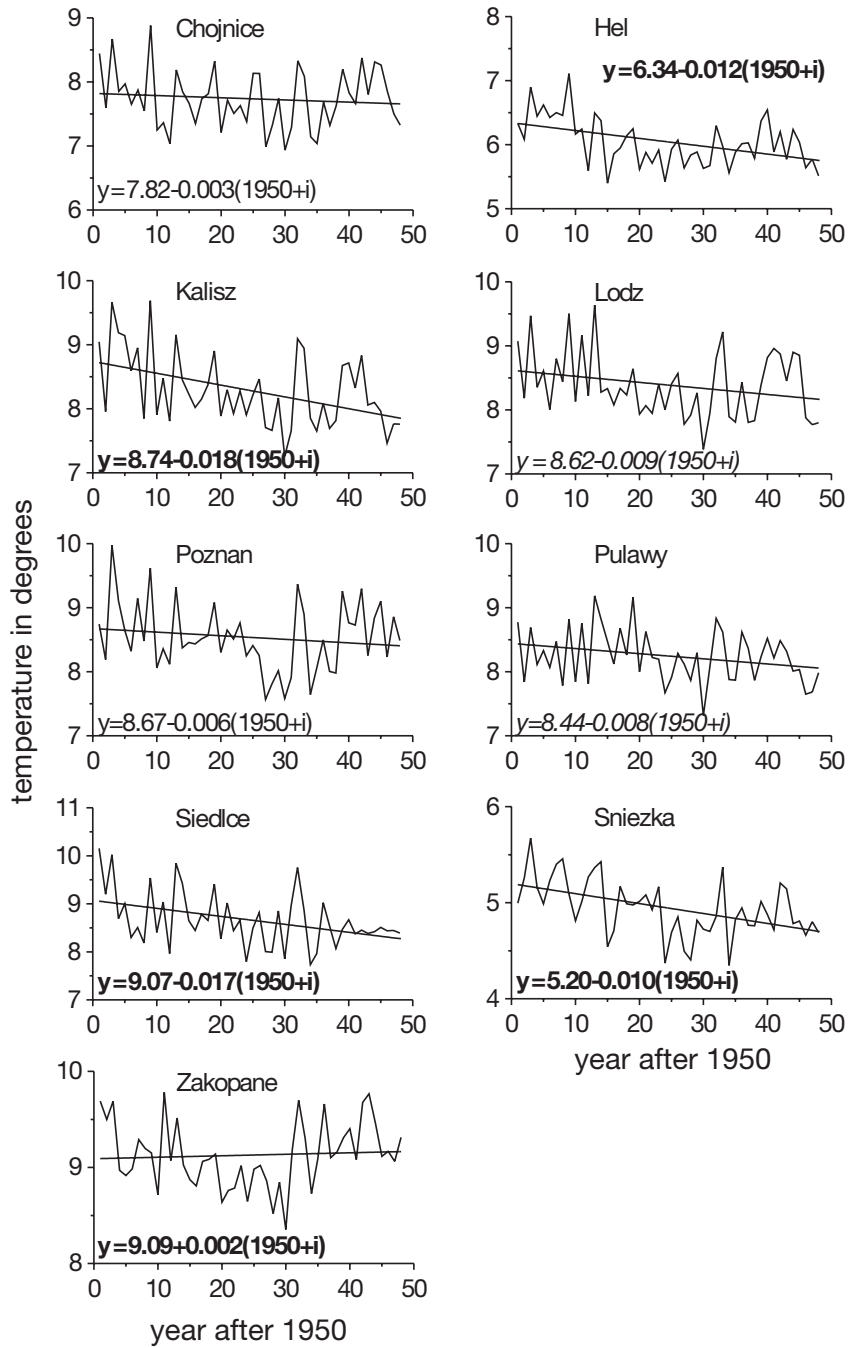

Fig. 3. Mean daily temperature range with linear trend. The trend equations statistically significant at $5 \%(10 \%)$ are given in bold (italics)

Global warming is manifest also in the decrease in the annual frequency of days with the minimum temperature below $0^{\circ} \mathrm{C}$ (i.e. cold days) (Fig. 4), according to both tests. This decrease varies from $0.4 \mathrm{~d}_{\text {decade }}{ }^{-1}$ in Zakopane to $6.0 \mathrm{~d}^{\text {decade }}{ }^{-1}$ in Hel. The number of such days varied at Śnieżka, which is located in the mountains, from 179 in 1961 to 234 in 1952 and in $\mathrm{Hel}_{\text {, }}$ which is located at the seaside, from 37 in 1990 to 125 in 1963 and 1996. This decrease is statistically significant at all stations, with the exception of Zakopane.

\subsection{Seasonal values (1951-1998)}

The mean maximum temperature shows an increase in winter and spring that is statistically significant at all sites with the exception of Śnieżka in spring (Table 3). The growth rate varies from 0.54 to $0.65^{\circ} \mathrm{C}_{\text {decade }}^{-1}$ in winter and from 0.25 to $0.40^{\circ} \mathrm{C}$ decade $^{-1}$ in spring. In autumn the mean maximum temperature decreases, with the rate varying from $0.18^{\circ} \mathrm{C}$ decade $^{-1}$ in Zakopane to $0.32^{\circ} \mathrm{C}$ decade $^{-1}$ in Siedlce. Summer changes are statistically insignificant.

The mean minimum temperature also shows an increase in winter and in spring. The rise is statistically significant at all sites and varies from 0.55 to $0.75^{\circ} \mathrm{C}$ decade $^{-1}$ in winter and from 0.25 to $0.43^{\circ} \mathrm{C}$ decade $^{-1}$ in spring. In other seasons changes are not significant.

The DTR generally decreases in winter (with the exception of Zakopane), but the changes are not significant. Only in autumn do statistically significant
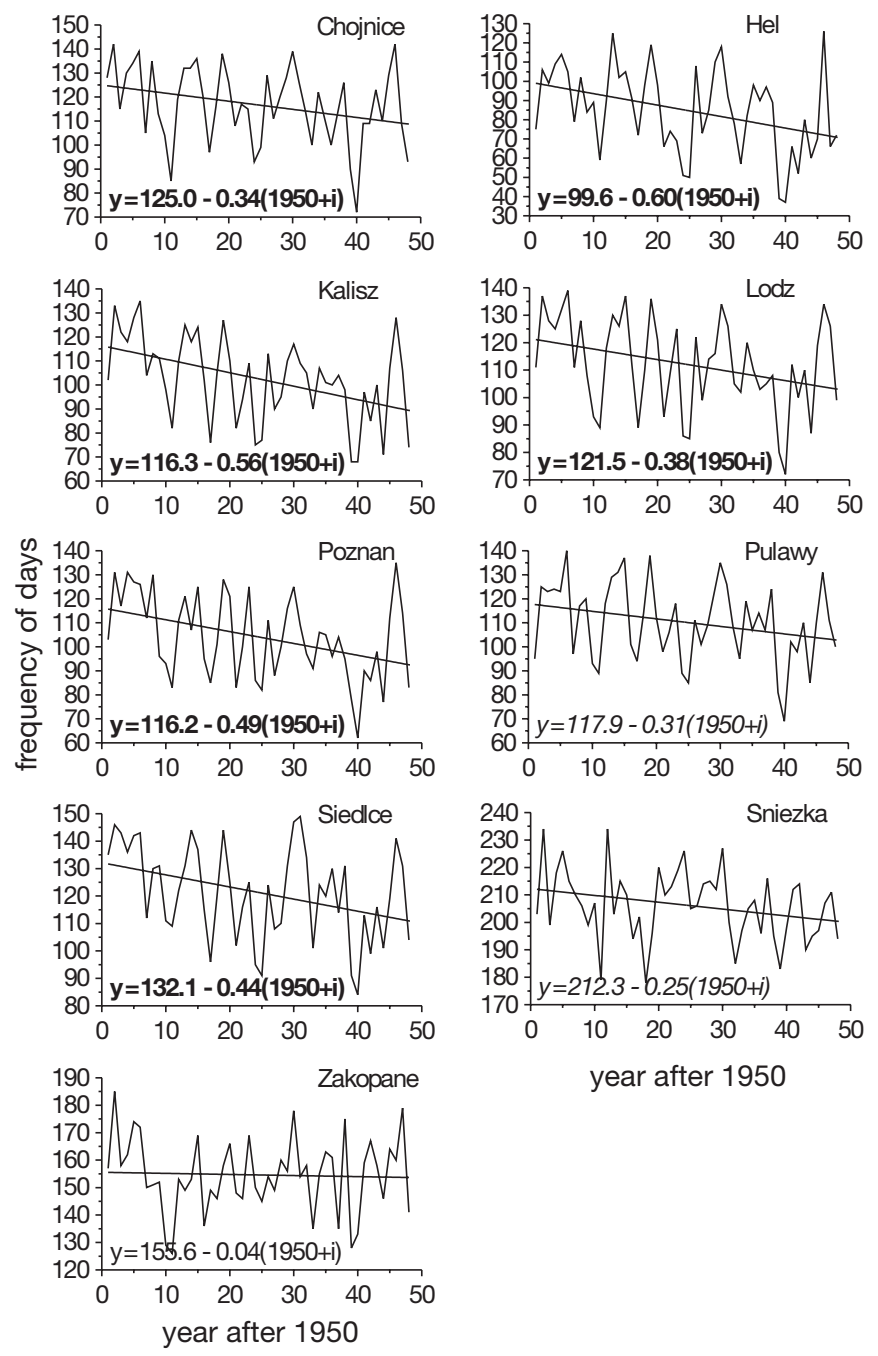

Fig. 4. Frequency of days with minimum temperature below $0^{\circ} \mathrm{C}$ with linear trend. The trend equations statistically significant at $5 \%(10 \%)$ are given in bold (italics) 
Table 3. Linear trend coefficient of selected temperature indices in the period 1951-1998 for $t_{\mathrm{n}}$ (mean minimum temperature), $t_{\mathrm{x} \text { }}$ DTR (daily temperature range), $\min t_{\mathrm{n}}$ and $\max t_{\mathrm{x}}\left({ }^{\circ} \mathrm{C}\right.$ decade $^{-1}$ ) and for $f_{C d}$ (frequency of days with minimum temperature below $0^{\circ} \mathrm{C}$, the so-called cold days) and $f w d\left(\mathrm{~d} \mathrm{decade}^{-1}\right)$. Values significant at $\alpha=0.05(0.10)$ are given in bold (italics)

\begin{tabular}{|c|c|c|c|c|c|c|c|c|c|}
\hline Season & Hel & Chojnice & Kalisz & Łódź & Poznań & Puławy & Siedlce & Śnieżka & Zakopane \\
\hline \multicolumn{10}{|l|}{$t_{\mathrm{n}}$} \\
\hline Spring & 0.43 & 0.31 & 0.42 & 0.35 & -0.34 & 0.36 & 0.36 & 0.25 & 0.27 \\
\hline Summer & 0.16 & -0.01 & 0.16 & 0.04 & -0.05 & 0.03 & -0.01 & 0.14 & 0.05 \\
\hline Autumn & -0.01 & -0.06 & -0.17 & 0.02 & -0.02 & 0.00 & 0.03 & -0.10 & -0.04 \\
\hline Winter & 0.55 & 0.61 & 0.73 & 0.65 & 0.70 & 0.64 & 0.75 & 0.58 & 0.56 \\
\hline \multicolumn{10}{|l|}{$t_{\mathrm{x}}$} \\
\hline Spring & 0.37 & 0.35 & 0.39 & 0.40 & 0.36 & 0.40 & 0.31 & 0.08 & 0.32 \\
\hline Summer & 0.03 & 0.05 & 0.02 & 0.01 & 0.00 & -0.01 & -0.14 & 0.00 & 0.10 \\
\hline Autumn & -0.22 & -0.23 & -0.29 & -0.29 & -0.22 & -0.28 & -0.32 & -0.22 & -0.18 \\
\hline Winter & 0.55 & 0.54 & 0.63 & 0.56 & 0.62 & 0.62 & 0.62 & 0.55 & 0.65 \\
\hline \multicolumn{10}{|l|}{ DTR } \\
\hline Spring & -0.06 & 0.03 & -0.03 & 0.05 & 0.02 & 0.05 & -0.04 & -0.18 & 0.05 \\
\hline Summer & -0.14 & 0.06 & -0.14 & -0.03 & 0.04 & -0.04 & -0.12 & -0.14 & 0.06 \\
\hline Autumn & -0.21 & -0.17 & -0.45 & -0.30 & -0.21 & -0.28 & -0.35 & -0.12 & -0.14 \\
\hline Winter & -0.07 & -0.07 & -0.10 & -0.09 & -0.08 & -0.02 & -0.12 & -0.03 & 0.09 \\
\hline \multicolumn{10}{|l|}{ fCd } \\
\hline Spring & -3.4 & -2.1 & -2.4 & -1.8 & -2.5 & -1.4 & -1.7 & -1.2 & -0.6 \\
\hline \multicolumn{10}{|l|}{ Summer } \\
\hline Autumn & 0.6 & 1.1 & -0.0 & 0.5 & 0.7 & 0.6 & 0.2 & -0.5 & 0.3 \\
\hline Winter & -4.3 & -3.4 & -4.5 & -3.8 & -4.5 & -3.7 & -4.0 & -1.6 & -1.6 \\
\hline \multicolumn{10}{|l|}{$f w d$} \\
\hline Spring & 1.0 & 1.0 & 0.9 & 0.9 & 1.2 & 0.9 & 0.5 & & 0.6 \\
\hline Summer & -0.1 & 0.1 & -0.5 & -0.5 & -0.7 & -0.5 & -1.0 & 0.2 & 0.9 \\
\hline Autumn & -1.1 & -0.8 & -0.7 & -0.6 & -0.7 & -0.7 & -0.8 & & -0.6 \\
\hline \multicolumn{10}{|l|}{ Winter } \\
\hline \multicolumn{10}{|l|}{$\min t_{\mathrm{n}}$} \\
\hline Spring & 0.60 & 0.64 & 0.82 & 0.66 & 0.61 & 1.00 & 0.87 & 0.52 & 0.94 \\
\hline Summer & 0.63 & 0.11 & 0.31 & -0.02 & 0.00 & 0.13 & 0.18 & 0.06 & 0.11 \\
\hline Autumn & -0.03 & -0.18 & -0.34 & -0.49 & -0.27 & -0.44 & -0.29 & -0.17 & -0.17 \\
\hline Winter & 0.54 & 0.39 & 0.93 & 0.79 & 1.07 & 0.51 & 1.91 & 0.19 & 0.80 \\
\hline \multicolumn{10}{|l|}{$\max t_{\mathrm{x}}$} \\
\hline Spring & 0.54 & 0.07 & 0.08 & 0.08 & -0.08 & -0.07 & -0.22 & 0.11 & 0.21 \\
\hline Summer & -0.06 & 0.44 & 0.44 & 0.24 & 0.28 & 0.06 & -0.02 & 0.25 & 0.05 \\
\hline Autumn & -0.66 & -0.69 & -0.96 & -0.72 & -1.00 & -0.55 & -0.59 & -0.44 & -0.21 \\
\hline Winter & 0.54 & 0.76 & 1.05 & 1.05 & 0.91 & 0.92 & 0.92 & 0.44 & 0.78 \\
\hline
\end{tabular}

trends occur. The rate of the decrease varies from $0.12^{\circ} \mathrm{C}$ decade ${ }^{-1}$ in Śnieżka to $0.45^{\circ} \mathrm{C}$ decade $^{-1}$ in Kalisz and is related to the decrease in the mean maximum temperature in autumn.

The absolute maximum temperature increases in winter, with the rate varying from $0.44^{\circ} \mathrm{C}$ decade $^{-1}$ in Śnieżka to $1.05^{\circ} \mathrm{C}$ decade ${ }^{-1}$ in Kalisz and Łódź. In autumn the absolute maximum temperature decreases significantly at all sites, with the exception of Zakopane (in Śnieżka at a significance level of $10 \%$ ), with the rate changing from $0.21^{\circ} \mathrm{C}_{\text {decade }}$ de $^{-1}$ in Zakopane to $1.00^{\circ} \mathrm{C}$ decade ${ }^{-1}$ in Poznań. In other seasons trends do not exceed the significance level.

The absolute minimum temperature generally has an increasing tendency from winter to summer and a decreasing tendency in autumn, but the changes are not statistically significant.

The frequency of days with the minimum temperature below $0^{\circ} \mathrm{C}$ (i.e. cold days) shows a decreasing trend in winter, varying from $1.6 \mathrm{~d}_{\text {decade }}{ }^{-1}$ in Śnieżka and Zakopane to $4.5 \mathrm{~d}_{\text {decade }}{ }^{-1}$ in Kalisz and Poznań. Low trends at the mountainous stations are the consequence of the fact that almost all days at these sites have a minimum temperature below $0^{\circ} \mathrm{C}$. The frequency of cold days decreases in spring also, with the rate varying from $0.6 \mathrm{~d}_{\text {decade }}$ de $^{-1}$ in Zakopane to $3.4 \mathrm{~d}$ decade $^{-1}$ in Hel. In autumn, however, the number of cold days increases (at all sites with the exception of Kalisz and Śnieżka), though the changes are not significant. 


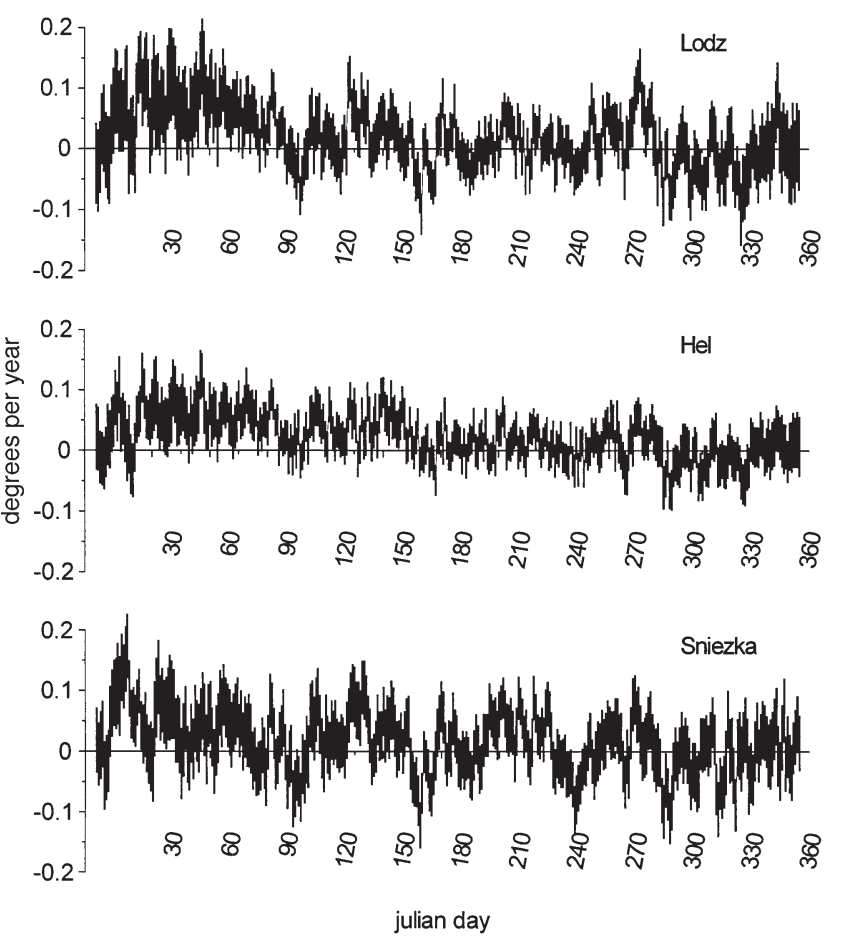

Fig. 5. Linear trend of the minimum daily temperatures in each calendar day in ${ }^{\circ} \mathrm{C} \mathrm{yr}^{-1}$ for the period 1951-1998 at selected stations

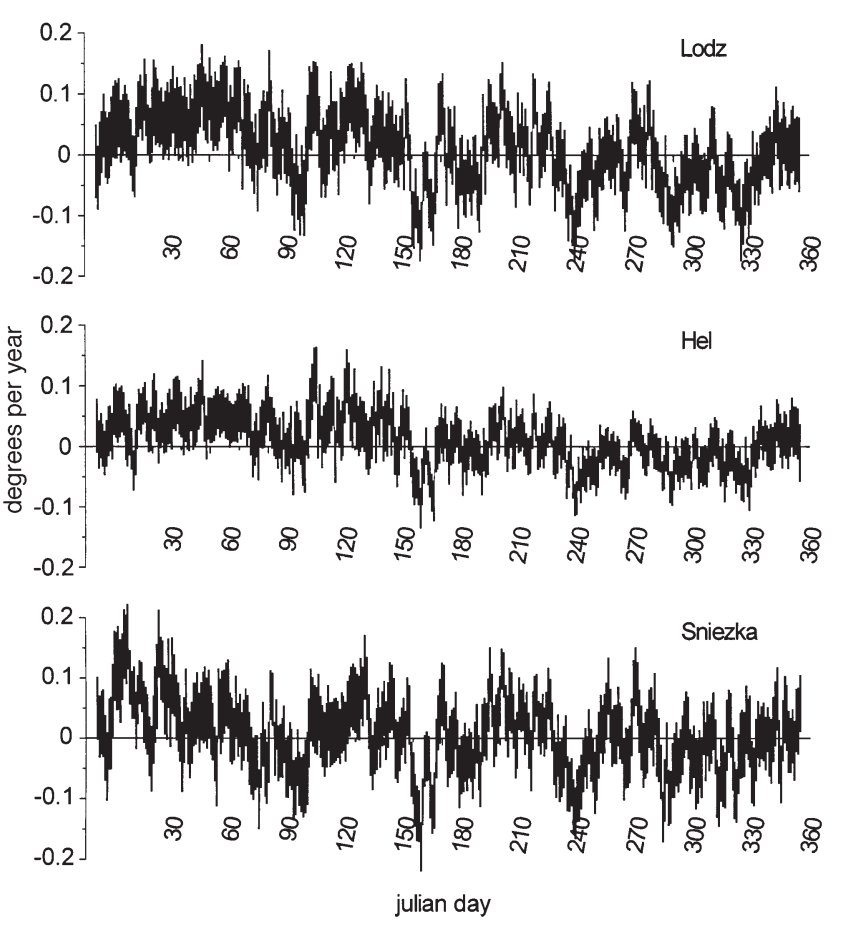

Fig. 6. Linear trend of the maximum daily temperatures in each calendar day in ${ }^{\circ} \mathrm{C}_{\mathrm{yr}^{-1}}$ for the period 1951-1998 at selected stations
The frequency of warm days (i.e. days with the maximum temperature above $20^{\circ} \mathrm{C}$ ) does not exhibit significant changes, but there is an increasing tendency in spring and a decreasing one in autumn.

\subsection{Intra-annual changes of the trends of minimum and maximum temperatures (1951-1998)}

In order to show the intra-annual changes of trends of minimum and maximum temperatures, they were calculated for each calendar day. The distributions of mean minimum and maximum temperatures on each calendar day do not differ significantly from the normal ones according to the Smirnov-Kolmogorov test, so the standard deviation was used to express the significance of trend. The minimum temperature exhibits the strongest increasing tendency at the beginning of the year (Fig. 5). Its rate is the highest during mid- and late winter, from mid-January to the end of March, and

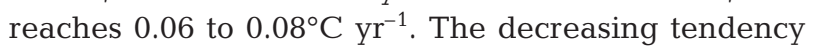
appears in late June and from the beginning of November to mid-December. Such a course for the linear trend values is close to equal at all the analyzed stations. The maximum temperature also increases at the beginning of the year (Fig. 6). This increase is a little slower and reaches 0.04 to $0.06^{\circ} \mathrm{C} \mathrm{yr}^{-1}$. In the rest of the year the periods with increasing temperature interlace with the periods of decreasing temperature. The decreases take place in late June, July, September, November and at the beginning of December.

\section{LONG-TERM CHANGES IN 20TH CENTURY}

On the basis of 4 long-term records, from Śnieżka, Zakopane, Puławy and Łódź (Table 1), the trends over longer periods were analyzed. The mean maximum temperature exhibits a slight increase in winter, spring and over the whole year. According to the MannKendall test and the test of significance of the trend coefficient, the increase in the annual mean is significant at Śnieżka only (Fig. 7, Table 4), in winter at Puławy and nowhere in spring. In autumn the decreasing trend is statistically significant at all sites with the exception of Śnieżka, where the maximum temperature increases. The annual mean minimum temperature significantly increases at all sites (Fig. 7). The rate of the rise is a little faster than $0.1^{\circ} \mathrm{C}$ decade $^{-1}$. This increase occurs mainly in spring and winter (Table 4). The mean annual DTR decreases significantly at all sites with a rate close to $0.06^{\circ} \mathrm{C}$ decade ${ }^{-1}$. The strongest decrease occurs in autumn and spring, when it is statistically significant at all analyzed stations. The annual frequency of cold days also decreases every- 

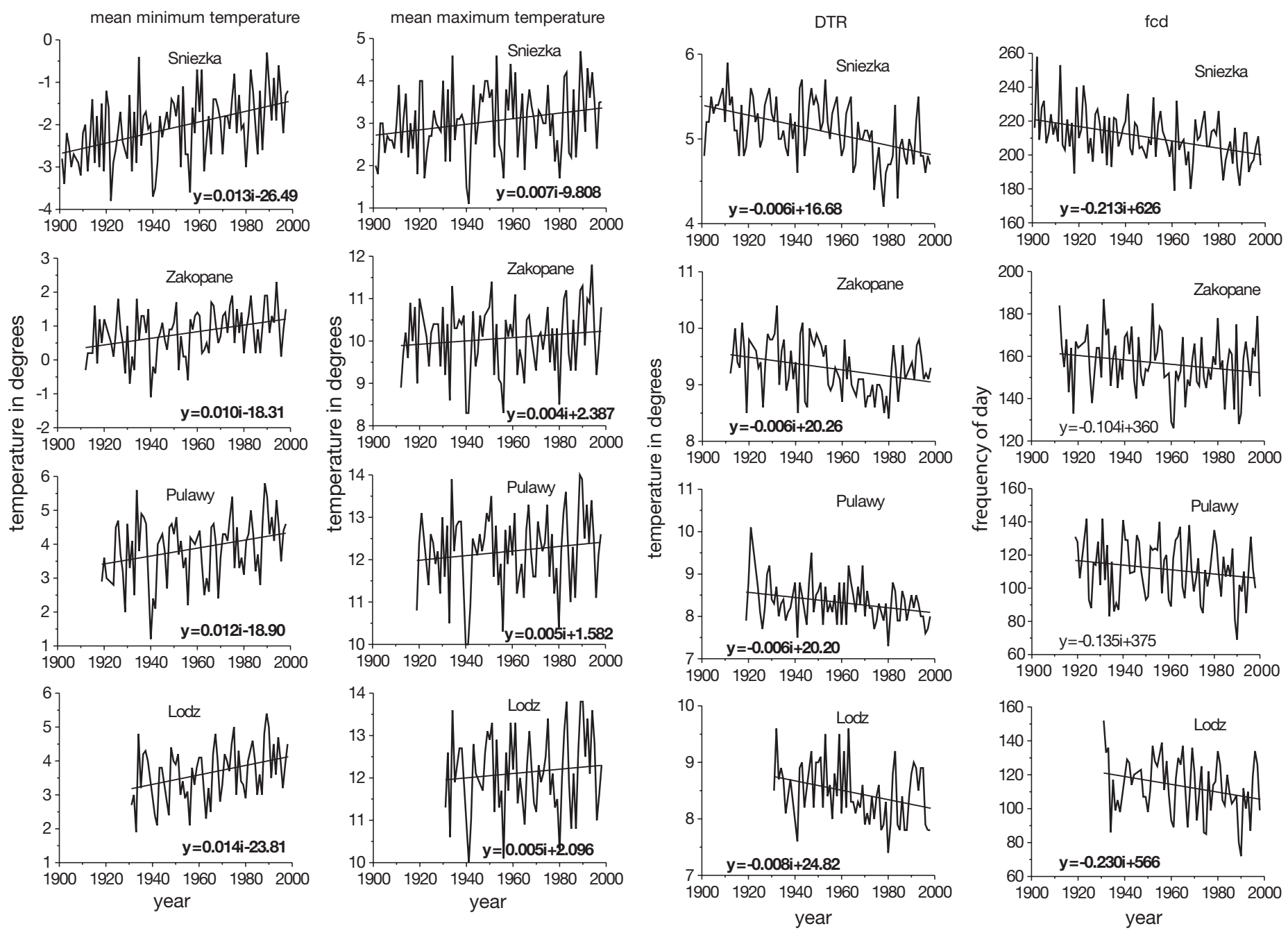

Fig. 7. Annual mean minimum and maximum temperatures, mean daily temperature range (DTR) and frequency of cold days $\left(f_{C d}\right)$ with linear trends at selected long-term stations. The trend equations statistically significant at $5 \%$ are given in bold

where, at a rate varying from $2.3 \mathrm{~d}_{\text {decade }^{-1}}$ in Łódź to $1.0 \mathrm{~d}$ decade $^{-1}$ in Zakopane. The decrease is statistically significant at all stations except for Zakopane. The strongest decrease occurs of course in winter; it is slighter in spring. The highest annual maximum temperature decreases at all sites, with the exception of Śnieżka. However, only the decrease at Zakopane and the increase at Śnieżka are significant (Table 4). The strongest decrease occurs in autumn. In winter the highest maximum temperature increases, and this rise is significant at all sites with the exception of Zakopane. The lowest annual minimum temperature also increases, and this rise is insignificant only in Łódź. The strongest increase occurs in winter (Table 4).

The main features of changes of minimum and maximum temperatures in the longer period are similar to those calculated for second half of 20th century, but the rate of changes is usually slower. This indicates an intensification of climate changes at the end of century, especially in the last 2 decades.

\section{RELATIONSHIPS BETWEEN CLOUDINESS AND TEMPERATURE CHARACTERISTICS}

With a probability of 66 to $90 \%$, the TAR states that the cloud cover over mid- and high-latitude land areas has increased by $2 \%$ and it is related to the observed decrease in the DTR in many countries. Karl et al. (1993) showed similar results. Only a few papers deal with cloudiness in Poland. Two of them (Matuszko 2000, Szyga-Pluta 2000) show trends in particular cloud types. This seems to be a good idea, because the transmission of solar radiation is different for different clouds, and the influence of thick Ns (nimbostratus) clouds is much stronger than the thin Cs (cirrostratus) 
Table 4. Values of the Mann-Kendall rank statistics for certain parameters at selected long-term stations. Bold values indicate statistical significance at $10 \%$ level. See Table 3 for abbreviation definitions

\begin{tabular}{|c|c|c|c|c|c|c|}
\hline & $t_{\mathrm{x}}$ & $t_{\mathrm{n}}$ & DTR & $f_{C d}$ & $\max t_{\mathrm{x}}$ & $\min t_{\mathrm{n}}$ \\
\hline \multicolumn{7}{|l|}{ Winter } \\
\hline Łódź & 1.60 & 1.62 & -1.17 & -2.05 & 1.96 & 2.13 \\
\hline Puławy & 1.97 & 1.74 & -1.54 & -1.79 & 1.74 & 1.41 \\
\hline Zakopane & 0.81 & 1.15 & -1.45 & -0.00 & 1.13 & 2.95 \\
\hline Śnieżka & 0.75 & 1.98 & -3.02 & & 1.36 & 1.54 \\
\hline \multicolumn{7}{|l|}{ Spring } \\
\hline Łódź & 1.07 & 2.33 & -1.83 & -2.09 & -1.84 & 0.72 \\
\hline Puławy & 0.67 & 1.58 & -1.85 & -1.03 & -0.74 & 0.74 \\
\hline Zakopane & 0.68 & 1.81 & -2.44 & -2.05 & -0.49 & 2.65 \\
\hline Śnieżka & 1.26 & 2.62 & -3.21 & & -0.62 & 1.48 \\
\hline \multicolumn{7}{|l|}{ Summer } \\
\hline Łódź & -1.36 & 0.77 & -2.29 & & -0.02 & 1.24 \\
\hline Puławy & 0.44 & 1.14 & -1.08 & & -1.57 & 2.45 \\
\hline Zakopane & -0.08 & 1.79 & -1.27 & & -2.02 & 3.38 \\
\hline Śnieżka & 2.03 & 4.67 & -3.86 & & 1.62 & 2.31 \\
\hline \multicolumn{7}{|l|}{ Autumn } \\
\hline Łódź & -2.57 & -0.50 & -3.60 & -0.05 & -2.54 & -1.39 \\
\hline Puławy & -1.97 & -0.27 & -3.68 & -0.40 & -2.16 & 0.75 \\
\hline Zakopane & -1.76 & 0.03 & -3.00 & -1.50 & -2.50 & 1.84 \\
\hline Śnieżka & 1.73 & 2.70 & -3.25 & & 0.30 & 0.97 \\
\hline \multicolumn{7}{|l|}{ Year } \\
\hline Eódź & 0.36 & 2.12 & -3.17 & -2.18 & -0.16 & 1.54 \\
\hline Puławy & 0.44 & 1.86 & -3.02 & -1.87 & -1.46 & 1.86 \\
\hline Zakopane & 0.16 & 2.19 & -3.22 & -1.47 & -1.81 & 3.60 \\
\hline Śnieżka & 2.34 & 5.02 & -4.98 & -3.78 & 1.89 & 1.97 \\
\hline
\end{tabular}
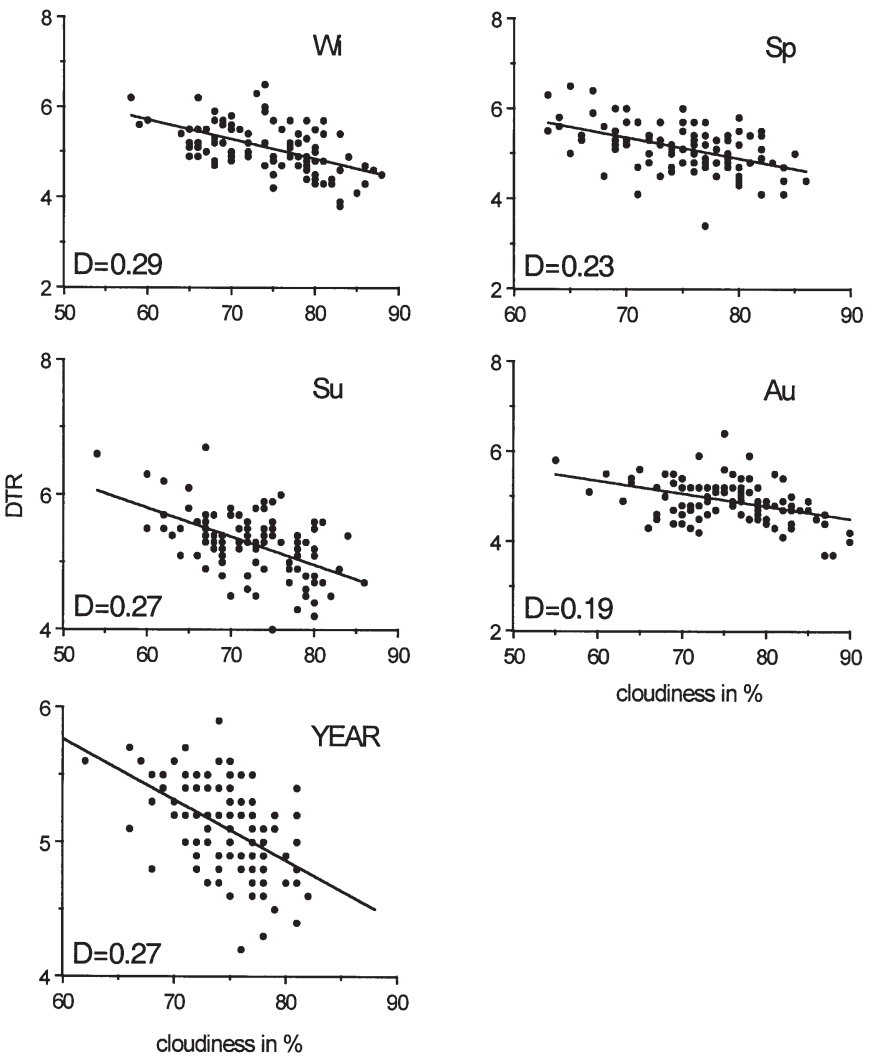

Fig. 8. Relations between seasonal cloudiness and mean DTR at Snieżka in the period 1901-1998 together with the determination coefficient $D$ ones. In Kraków, in the south of Poland, there is an increasing trend of Ac (altocumulus) and Sc (stratocumulus) clouds, the 2 most frequent ones, in the 20th century. There is also a decreasing trend of Ns clouds, which are also quite frequent (Matuszko 2000). In Poznań, the most frequent clouds are Sc $(23 \%)$, Ac (13\%), Ci (cirrus; $17 \%$ ) and $\mathrm{Cu}$ (cumulus; $15 \%$ ). In the period 1966-1990 the frequency of occurrence of Ac, $\mathrm{Ci}$ and $\mathrm{Cu}$ clouds slightly increased, with a stable number of Sc clouds (Szyga-Pluta 2000). In Poznań, however, the DTR has not decreased.

Miętus \& Owczarek (1994) analyzed the trend of annual values of cloudiness at seaside stations over the period 1945-1990. They found a decreasing tendency; but it was only statistically significant at 1 site. At all stations, however, correlation coefficients of cloudiness and the DTR were negative and statistically significant.

In this paper, the record of mean annual and seasonal cloudiness at Śnieżka in the 20th century was related to the annual and seasonal values of the DTR. The correlation coefficients were statistically significant in all seasons, pointing to strong relations between the DTR and the overall cloudiness (Fig. 8).

The cloudiness at Śnieżka exhibits a positive linear trend in all seasons, but it is only statistically significant in spring $\left(0.38 \%\right.$ decade $\left.^{-1}\right)$ (Dubicka \& Głowicki 2000). These values may be related to the variations of 
Table 5. Correlation coefficients $(R)$ of cloudiness in Łódź and DTR over the period 1951-1995 and linear trend (A) of DTR as a function of cloudiness in degrees per $1 \%$. Statistically significant correlation values are given in bold

\begin{tabular}{|llllll|}
\hline & Spring & Summer & Autumn & Winter & Year \\
\hline$R$ & $\mathbf{- 0 . 5 8}$ & $\mathbf{- 0 . 6 5}$ & $\mathbf{- 0 . 6 6}$ & $\mathbf{- 0 . 4 4}$ & $\mathbf{- 0 . 5 9}$ \\
$A$ & -0.078 & -0.087 & -0.086 & -0.045 & -0.083 \\
\hline
\end{tabular}

the composition of the atmosphere, which is strongly connected with the dynamic development of mining and power industry after the 1950s in the so-called Black Triangle-Polish, Czech and German borderlands in the western Sudety Mountains.

The daily values of mean cloudiness in Łódź in the period 1951-1995 were also related to the DTR. In all seasons and over the whole year, correlation coefficients were negative and statistically significant (Table 5). It means that higher cloudiness is accompanied by a lower DTR.

\section{RELATIONSHIPS BETWEEN THE NAO INTENSITY AND THE EXTREME TEMPERATURE CHARACTERISTICS}

In Europe, the variability of temperature is strongly related to NAO variations (Wibig 1996, Hurrell \& van Loon 1997). To analyze if the relation is also evident in the case of the maximum and minimum temperatures and their characteristics, the correlations between the NAO index, as defined by Jones et al. (1997), and all the selected indices were calculated for all seasons and the whole year for the period 1951-1998.

The mean minimum and maximum temperatures have positive correlations with the NAO index in all seasons but summer, when they are negative and statistically insignificant (Table 6). The strongest relations are for the mean maximum temperature in winter, the weakest for the minimum temperature in autumn (significant at only 4 sites). The yearly correlations vary from 0.49 to 0.58 for the mean maximum temperature and from 0.41 to 0.53 for the mean minimum temperature.

The relations of the DTR with the NAO are much weaker. They are positive over the whole year and in autumn and negative in winter, because in winter the NAO has a stronger influence on the mean maximum temperature than the mean minimum temperature.

The strong NAO generally decreases the frequency of cold days. The relation is statistically significant in winter, spring and over the whole year, and below the significance level in autumn. Such days do not occur in summer. The frequency of warm days is significantly related to the NAO intensity in autumn only, when the correlations are positive. In summer and sometimes in spring, intensification of the NAO brings a lower than usual number of warm days. In winter such days do not occur.

The intense NAO is related to the lowest minimum temperature in winter, spring and over the whole year. The majority of the correlations are statistically significant. In autumn and summer negative correlations are common, but they do not exceed the significance level. The highest maximum temperature is higher than usual in autumn and winter during the years in which the NAO was strong. The relationship is the strongest in autumn, when all correlation coefficients are statistically significant, and they vary from 0.29 in Zakopane to 0.5 in Hel. In spring the correlations are mainly negative and insignificant.

\section{DISCUSSION AND CONCLUSIONS}

The linear increase in mean annual daily minimum temperature in Poland was evidently higher than that of mean daily maximum temperature at all stations in the longer periods and at all stations but 2 in the shorter one (1951-1998). The resulting decrease in the DTR is statistically significant. Also the decrease in frequency of days with minimum temperature below $0^{\circ} \mathrm{C}$ is clear and results in prolongation of the freeze-free season. All these results are consistent with TAR statements. Our results differ substantially from those presented by Brázdil et al. (1996), because the period of our analysis is longer and includes not only the very warm 1990s but also the data from the first part of the 20th century. The strong influence of the 1990s on trends is evident in Figs. 2-4 \& 7. The increasing trends exhibit a distinct annual course. The strongest warming was found during mid- and late winter for both the maximum and minimum temperatures. There are also subperiods when the decreasing tendency dominates, particularly well expressed in late autumn and early winter (November and the first part of December) and at the beginning of summer (June).

The evident increase in the minimum temperature indices together with a smaller increase $\left(t_{\mathrm{x}}\right)$ or even a decrease $\left(\max _{\mathrm{x}}\right)$ in maximum temperature indices indicates the transition to a more maritime climate, 
Table 6. Correlation coefficients of selected temperature indices with mean seasonal and annual NAO values over the period 1951-1998. Statistically significant values for $\alpha=0.05(0.10)$ are given in bold (italics)

\begin{tabular}{|c|c|c|c|c|c|}
\hline Stn & Spring & Summer & Autumn & Winter & Year \\
\hline \multicolumn{6}{|l|}{$t_{\mathrm{x}}$} \\
\hline Chojnice & 0.42 & -0.03 & 0.45 & 0.57 & 0.54 \\
\hline Hel & 0.55 & -0.05 & 0.56 & 0.57 & 0.58 \\
\hline Kalisz & 0.44 & -0.10 & 0.43 & 0.54 & 0.58 \\
\hline Łódź & 0.43 & -0.06 & 0.39 & 0.54 & 0.55 \\
\hline Poznań & 0.46 & -0.05 & 0.45 & 0.55 & 0.55 \\
\hline Puławy & 0.43 & -0.04 & 0.35 & 0.52 & 0.53 \\
\hline Siedlce & 0.41 & -0.05 & 0.39 & 0.54 & 0.49 \\
\hline Śnieżka & 0.29 & -0.08 & 0.45 & 0.39 & 0.51 \\
\hline Zakopane & 0.24 & -0.11 & 0.32 & 0.46 & 0.53 \\
\hline \multicolumn{6}{|l|}{$t_{\mathrm{n}}$} \\
\hline Chojnice & 0.44 & -0.19 & 0.37 & 0.56 & 0.53 \\
\hline $\mathrm{Hel}$ & 0.47 & -0.16 & 0.49 & 0.53 & 0.49 \\
\hline Kalisz & 0.42 & -0.19 & 0.13 & 0.51 & 0.41 \\
\hline Łódź & 0.36 & -0.07 & 0.18 & 0.52 & 0.42 \\
\hline Poznań & 0.37 & -0.07 & 0.29 & 0.53 & 0.47 \\
\hline Puławy & 0.40 & -0.11 & 0.19 & 0.51 & 0.43 \\
\hline Siedlce & 0.35 & -0.01 & 0.13 & 0.52 & 0.44 \\
\hline Śnieżka & 0.34 & -0.16 & 0.35 & 0.41 & 0.49 \\
\hline Zakopane & 0.27 & -0.06 & 0.09 & 0.46 & 0.45 \\
\hline \multicolumn{6}{|l|}{ DTR } \\
\hline Chojnice & 0.15 & 0.07 & 0.18 & -0.35 & 0.21 \\
\hline $\mathrm{Hel}$ & 0.30 & 0.07 & 0.26 & -0.09 & 0.26 \\
\hline Kalisz & 0.24 & 0.01 & 0.36 & -0.23 & 0.35 \\
\hline Łódź & 0.33 & -0.02 & 0.35 & -0.28 & 0.38 \\
\hline Poznań & 0.30 & -0.02 & 0.25 & -0.28 & 0.30 \\
\hline Puławy & 0.24 & 0.03 & 0.28 & -0.34 & 0.27 \\
\hline Siedlce & 0.16 & -0.05 & 0.31 & -0.37 & 0.08 \\
\hline Śnieżka & -0.10 & 0.12 & 0.35 & -0.06 & 0.13 \\
\hline Zakopane & -0.02 & -0.10 & 0.39 & -0.12 & 0.36 \\
\hline \multicolumn{6}{|l|}{ fcd } \\
\hline Chojnice & -0.54 & & -0.23 & -0.52 & -0.60 \\
\hline Hel & -0.48 & & -0.13 & -0.57 & -0.58 \\
\hline Kalisz & -0.48 & & -0.13 & -0.45 & -0.52 \\
\hline Łódź & -0.47 & & -0.16 & -0.54 & -0.52 \\
\hline Poznań & -0.49 & & -0.14 & -0.52 & -0.54 \\
\hline Puławy & -0.47 & & -0.11 & -0.52 & -0.47 \\
\hline Siedlce & -0.42 & & -0.14 & -0.52 & -0.43 \\
\hline Śnieżka & -0.16 & & -0.20 & -0.12 & -0.24 \\
\hline Zakopane & -0.31 & & -0.23 & -0.25 & -0.30 \\
\hline \multicolumn{6}{|l|}{ fwd } \\
\hline Chojnice & -0.03 & -0.06 & 0.33 & & 0.12 \\
\hline Hel & 0.04 & -0.05 & 0.32 & & 0.14 \\
\hline Kalisz & 0.04 & -0.08 & 0.34 & & 0.23 \\
\hline Łódź & 0.04 & -0.08 & 0.27 & & 0.19 \\
\hline Poznań & 0.15 & -0.01 & 0.33 & & 0.23 \\
\hline Puławy & -0.03 & -0.17 & 0.15 & & 0.05 \\
\hline Siedlce & -0.03 & -0.21 & 0.18 & & -0.05 \\
\hline Śnieżka & 0.00 & 0.00 & 0.34 & & 0.13 \\
\hline Zakopane & -0.21 & 0.03 & 0.22 & & 0.17 \\
\hline \multicolumn{6}{|l|}{$\min t_{\mathrm{n}}$} \\
\hline Chojnice & 0.30 & -0.01 & 0.07 & 0.48 & 0.29 \\
\hline Hel & 0.31 & 0.20 & 0.07 & 0.45 & 0.27 \\
\hline Kalisz & 0.30 & -0.03 & -0.04 & 0.34 & 0.29 \\
\hline Łódź & 0.31 & -0.00 & -0.02 & 0.32 & 0.29 \\
\hline Poznań & 0.25 & -0.03 & -0.05 & 0.42 & 0.28 \\
\hline Puławy & 0.44 & 0.11 & -0.06 & 0.37 & 0.29 \\
\hline Siedlce & 0.47 & 0.07 & -0.02 & 0.28 & 0.34 \\
\hline Śnieżka & 0.33 & 0.11 & -0.01 & 0.22 & 0.14 \\
\hline Zakopane & 0.38 & 0.17 & 0.00 & 0.18 & 0.32 \\
\hline
\end{tabular}


Table 6 (continued)

\begin{tabular}{|c|c|c|c|c|c|}
\hline Stn & Spring & Summer & Autumn & Winter & Year \\
\hline \multicolumn{6}{|l|}{$\max t_{\mathrm{x}}$} \\
\hline Chojnice & -0.27 & 0.05 & 0.40 & 0.33 & 0.36 \\
\hline $\mathrm{Hel}$ & 0.04 & 0.09 & 0.39 & 0.40 & 0.29 \\
\hline Kalisz & -0.19 & -0.10 & 0.50 & 0.36 & 0.27 \\
\hline Łódź & -0.18 & 0.02 & 0.49 & 0.31 & 0.23 \\
\hline Poznań & -0.29 & -0.01 & 0.45 & 0.32 & 0.34 \\
\hline Puławy & -0.16 & 0.04 & 0.32 & 0.31 & 0.26 \\
\hline Siedlce & -0.21 & 0.09 & 0.34 & 0.34 & 0.26 \\
\hline Śnieżka & -0.17 & -0.09 & 0.38 & -0.04 & 0.09 \\
\hline Zakopane & -0.22 & -0.25 & 0.29 & 0.25 & 0.13 \\
\hline
\end{tabular}

which is related to the intensity of the NAO. Such a suggestion is confirmed by strong correlations of these indices with the NAO index, especially during winter and spring. The observed rise in cloudiness at Śnieżka can also be related to more oceanic climate conditions.

The important feature of the observed changes is a statistically significant cooling in autumn. This should be related to changes in atmospheric circulation. The NAO index shows a slightly decreasing tendency in autumn, but the change is statistically insignificant.

The relations between cloudiness and the DTR at Śnieżka and Łódź confirm the relations postulated by Karl et al. (1993) and presented in TAR, irrespective of whether it is a direct or indirect effect related to the NAO intensity. It should be noted that the rise in cloudiness at Śnieżka is insignificant in spite of the fact that the atmospheric concentration of sulfate and other aerosols has evidently dropped in the last decade.

Acknowledgements. The authors wish to thank the Institute of Meteorology and Water Management for kindly providing the data and the 3 anonymous reviewers for constructive comments. The work of J.W. was supported by the Polish Committee of Scientific Research under grant 6 PO4E 01216.

\section{LITERATURE CITED}

Alexandersson H (1986) A homogeneity test applied to precipitation data. J Clim 6:661-675

Böhm R, Auer I (1994) A search for greenhouse signal using daytime and nighttime temperature series. In: Heino $\mathrm{R}$ (ed) Climate variations in Europe. Academy of Finland, Painatuskeskus, Helsinki, p 141-151

Brázdil R, Machu R, Budíková M (1994) Temporal and spatial changes in maxima and minima of air temperature in the Czech Republic in the period of 1951-1993. In: Brázdil R, Kolár M (eds) Contemporary climatology. Brno, p 93-102

Brázdil R, Budíková M, Auer I, Böhm R and 10 others (1996) Trends of maximum and minimum daily temperatures in Central and Southeastern Europe. Int J Climatol 16: $765-782$

Editorial responsibility: Hans von Storch, Geesthacht, Germany
Dubicka M, Głowicki B (2000) Air temperature and cloudiness at Śnieżka between 1901 and 1998. Zesz Nauk UJ Prace Geogr 107:207-212

Głowicki B (1998) Wieloletnia seria pomiarów temperatury powietrza na Snieżce. (Long-term record of air-temperature measurements at Snieżka). In: Geoekologiczne Problemy Karkonoszy 1, Wyd. Acarus, Poznań, p 117-123

Hurrell JW, van Loon H (1997) Decadal variations in climate associated with North Atlantic Oscillation. In: Climatic Change Special Issue Summary of the International Workshop on Climatic Change at High Elevation Sites, September 1995. Wengen. Climate Change 36:301-306

Jones PD, Jonsson T, Wheeler D (1997) Extension to the North Atlantic Oscillation using early instrumental pressure observations from Gibraltar and South-West Iceland. Int J Climatol 17:1433-1450

Karl TR, Jones PD, Knight RW, Kukla G and 6 others (1993) A new perspective on recent global warming: asymmetric trends of daily maximum and minimum temperature. Bull Am Meteorol Soc 74:1007-1023

Lapin M, Faško P (1994) Daily air temperature range and relative air humidity correlation at Hurbanovo. In: Brázdil $\mathrm{R}_{\text {, }}$ Kolár M (eds) Contemporary climatology. Brno, p 359-363

Matuszko D (2000) Long-term observation of cloud cover in Cracow (1792-1999). Zesz Nauk UJ Prace Geogr 107: 243-250

Miętus M, Owczarek M (1994) Variability of mean annual amplitude of air temperature in relation to the mean cloudiness on the Polish coast since 1945. In: Heino R (ed) Climate variations in Europe. Academy of Finland, Painatuskeskus, Helsinki, p 128-137

Niedźwiedź T, Ustrnul Z (1994) Maximum and minimum temperatures in Poland and the variability of atmospheric circulation. In: Brázdil R, Kolár M (eds) Contemporary climatology. Brno, p 420-425

Szyga-Pluta K (2000) The frequency of occurrence of cloud types in Poznan in the period 1966-1990. Proc of the Conf on Changes and Variability of Climate in Poland, November 1999. Łódź, p 251-256 (in Polish)

Weber GR (1994) On the seasonal variation of local relationships between temperature, temperature range, sunshine and cloudiness. Theor Appl Climatol 50:15-22

Wibig J (1996) Spatial distribution of temperature in Europe according to circulation patterns at $500 \mathrm{hPa}$. In: Nemesova I (ed) Proc of the Regional Workshop, Prague, Czech Rep. 11-15 September 1995. Czech Academy of Science, Prague, p 65-70

Submitted: March 13, 2001; Accepted: July 23, 2001

Proofs received from author(s): January 24, 2002 